\title{
Causes of Male Infertility
}

\section{Erkek Infertilite Nedenleri}

\author{
Münevver Serdaroğulları, ${ }^{1,2}$ \\ 'Department of Embryology, British Cyprus IVF Hospital, Nicosia, Cyprus \\ 2 Faculty of Medicine, Cyprus International University, Nicosia, Cyprus
}

ORCID ID: M.S. 0000-0001-5196-297X

Cite this article as: Serdaroğulları, M. Causes of Male Infertility. Experimed 2020; 10(3): 144-7.

\begin{abstract}
Infertility is a global health problem and is defined as an inability to achieve a clinical pregnancy after 12 months of regular unprotected sexual intercourse. The global incidence of infertility is approximately $8-12 \%$, and half of these patients seek medical help for the condition. The use of assisted reproduction technology (ART) has been increasingly used worldwide, and advances in ART have enabled many couples to overcome infertility. Infertility can be related to female infertility, male infertility, a combination of the two or unexplained factors. Male infertility constitutes nearly half of all instances of infertility and affects approximately $7 \%$ of the male population. The initial evaluation of male infertility includes obtaining a detailed medical history, a physical examination, an endocrine assessment and semen analysis. Male infertility can be due to hormonal imbalances, genetic problems, physical causes, environmental lifestyle factors or psychological or behavioural factors. Also, advanced male age may affect the quality of sperm, which can lead to male infertility. In conclusion, the causes of male infertility are multifarious. The evaluation and management of male infertility during infertility treatment are of the utmost importance for couples.
\end{abstract}

Keywords: Male infertility, infertility

Infertility is a global health problem and is defined as an inability to achieve a clinical pregnancy after 12 months of regular unprotected sexual intercourse (1). The global incidence of infertility is approximately $8-12 \%$, and half of these patients seek medical help for the condition (2). Assisted reproduction technology (ART) has been increasingly used worldwide, and advances in ART have enabled many couples to overcome infertility. Infertility can be related to female infertility, male infertility, a combination of the two or unexplained factors. Male infertility constitutes nearly half of all instances of infertility and affects approxi-

\section{öz}

İnfertilite dünya çapında bir sağlık sorunu olup, 12 aylık düzenli korunmasız cinsel ilişkiden sonra klinik bir hamilelik elde edememe olarak tanımlanmaktadır. Dünya çapında infertilitenin insidansı yaklaşık \%8-12 olarak belirtilmekle birlikte hastaların yarısı bu durum için tıbbi yardım istemektedir. Yardımcı üreme teknolojisinin (YÜT) kullanımı dünya çapında giderek artmakla birlikte, YÜT'deki gelişmeler birçok çiftin infertilite sorunun üstesinden gelmesine izin vermiştir. İnfertilite, kadın infertilitesi, erkek infertilitesi, kadın ve erkek veya açıklanamayan faktörlerin bir kombinasyonu ile ilişkili olabilmektedir. Erkek infertilitesi, tüm infertilite vakalarının neredeyse yarısını oluşturur ve erkek nüfusun yaklaşık \%7'sini etkilemektedir. Erkek infertilitesinin ilk değerlendirmesi, ayrıntılı bir tıbbi öykü, fizik muayene, endokrin değerlendirme ve semen analizini içermektedir. Erkek infertilitesi hormonal dengesizlikler, genetik problemler, fiziksel nedenler, çevresel yaşam tarzı faktörleri veya psikolojik veya davranışsal faktörlerden kaynaklanabileceği raporlanmıştır. Ayrıca, ileri erkek yaşı, sperm kalitesini etkileyerek erkek infertilitesine yol açabilir. Sonuç olarak, erkek infertilitesinin nedenleri çok yönlüdür. İnfertilite tedavisi sırasında erkek infertilitesinin değerlendirilmesi ve yönetimi çiftler için son derece önemlidir.

Anahtar Kelimeler: Erkek infertilitesi, infertilite

mately $7 \%$ of the male population (3). The initial evaluation of male infertility includes obtaining a detailed medical history, a physical examination, an endocrine assessment and semen analysis. The parameters assessed in a semen analysis are the sperm concentration, motility and morphology, and the semen volume and $\mathrm{pH}$. The sperm vitality, the presence of leukocytes, and the number of immature germ cells are also assessed and compared to reference values from the World Health Organization (WHO) (1).

It is well documented that male infertility can be due to hormonal imbalances, genetic problems, physical causes, 
or psychological or behavioural factors. Malnutrition, anaemia, excessive stress and exposure to environmental hazards such as pesticides, lead paint, radioactive substances, mercury, benzene, boron and heavy metals have also been reported to cause male infertility (4-6). Furthermore, advanced male age may affect the quality of sperm, which can lead to male infertility (7).

Spermatogenesis and steroidogenesis (steroid hormone production) are the main functions of the testis. Spermatogenesis is the process by which spermatogonia transform into mature spermatozoa through mitotic and meiotic division (8). Spermatogenesis begins at puberty and occurs in the epithelium of seminiferous tubules in the testis. The induction of spermatogenesis and the persistence of sperm production are regulated through the hypothalamic-pituitary-gonadal axis. In the seminiferous tubules, Sertoli cells are the main cell type, while Leydig cells predominate in the interstitium, which is another main compartment of the testis that consists of loose connective tissue along with blood and lymph vessels (9-11). Testosterone, follicle-stimulating hormone (FSH) and luteinizing hormone ( $\mathrm{LH})$ participate in spermatogenesis. The synthesis of these hormones is stimulated by gonadotropin-releasing hormone $(\mathrm{GnRH})$, which is secreted from the hypothalamus. Testosterone production occurs in Leydig cells and is induced by LH. FSH acts on Sertoli cells to support the synthesis of androgen-binding protein and the blood-testis barrier. GnRH secretion disorder causes testosterone deficiency and impairs sperm production (12).

Genetic factors that cause male infertility are heterogeneous. Chromosomal abnormality is defined as any alteration in one or more chromosomes and is categorised as either numerical or structural. Numerical abnormality is when a chromosome is missing or when there is an extra chromosome. For instance, Klinefelter syndrome, the presence of an extra X chromosome in men, is the most common numerical abnormality in men with impaired spermatogenesis (13-15). By contrast, the modification of chromosomal structures, such as translocations, inversions, $Y$ chromosome microdeletions and copy number variations (CNVs), are defined as structural chromosomal abnormalities. Translocations can be Robertsonian (where a whole chromosome has joined to another at the centromere) or reciprocal (sections from two distinct chromosomes have been swapped). Translocations are 10 times more common among infertile men compared with the normal population. These translocations can lead to decreased fertility, spontaneous abortion and birth defects (16). Inversions occur when a piece of a chromosome rotates 180 degrees within the same chromosome; thus, there is no loss of genetic material (17). Like translocations, inversions may cause infertility, spontaneous abortions and birth defects (16-18). Y chromosome microdeletions may also be a cause of spermatogenetic failure. Three regions on the long arm (Yq) of the $Y$ chromosome have been identified: the azoospermia factors (AZFs) AZFa, AZFb and AZFc. Any deletions in these regions might cause male infertility (19). CNVs are large DNA segments that repeat in the ge- nome; the number of repeats varies among individuals $(20,21)$. CNVs have been found to cause spermatogenetic failure by affecting genes that are essential for spermatogenesis $(22,15)$.

Spermatogenesis is a complex process, and large numbers of genes are present during this event. Gene mutations that cause abnormal spermatogenesis without any other symptoms give rise to non-syndromic male infertility (23). Identified gene mutations have been generally grouped according to the resulting phenotype, such as spermatogenic failure, teratozoospermia and asthenozoospermia (13). Technological advances have enabled researchers to analyse the whole genome to identify various specific gene mutations that lead to male infertility (24). However, no single gene is known to cause male infertility (25). Some genes are notable owing to their prevalence in specific groups. AURKC and DPY19L2 mutations have been related to teratozoospermia $(26,27)$. Two recurrent mutations have been identified for AURKC: one in the North African population and one in the European population. A carrier frequency of 1/50 was established in North African patients who had macrocephaly (large head and multi-tailed spermatozoa) (26). Later, it was demonstrated that the majority of macrocephalic spermatozoa are tetraploid, meaning that they have no chance of intracytoplasmic sperm injection (ICSI) (28). Mutations in the DPY19L2 gene have been correlated with globozoospermia (round-headed spermatozoa); this mutation is found in $60 \%$ of globozoospermic patients (27). It has been demonstrated that assisted oocyte activation enables better fertilization rates (29). Although there is no dominant gene yet to be the reason for spermatogenic failure, it has been reported that TEX11 mutation can cause meiotic arrest and azoospermia with a frequency of $2-15 \%$ in azoospermic men $(8,13,30)$. Furthermore, although there is limited evidence, mutations in TEX15 are thought to cause spermatogenic failure and a decreased sperm count over time. Patients with this mutation could be advised to undergo sperm cryopreservation at an early age with the aim of protecting future fertility potential (31). According to a recent study, it has been demonstrated that M1AP mutation can cause severe spermatogenic failure leading to male infertility. In the study, they were able to trace M1AP mutation in different independent patients in different countries and concluded that M1AP should be included in the growing list of validated non-obstructive azoospermia (NOA) genes (32). In recent years, due to the discovery and presence of various specific gene mutations, there are few custom gene panels for infertility that are available as a diagnostic tool. Genes included in each custom panel are different but in general, gene panels would provide a definitive causal diagnosis and more accurate treatment in ART (33-36).

Physical problems can decrease the sperm count and/or sperm morphology. Varicocele is a congenital vascular anomaly that causes impaired sperm motility, decreased sperm count, and impaired sperm structure (37). Moreover, in some infertile men, sperm cannot travel from the testicles to the penis because of sperm duct obstruction. The blockage or deficiency of one or both tubes can be caused by genetic or developmental factors. 
Torsion occurs when the testicle is bent in the scrotum and is characterized by excessive swelling. This leads to testicular damage because the blood vessels that feed the testicle are compressed. Furthermore, infections and diseases such as tuberculosis, brucellosis, gonorrhoea, typhoid, flu, chickenpox, rubella and syphilis can cause obstructions and testicular atrophy (38). These conditions can lead to changes in sperm quality by decreasing the sperm count and motility. Retrograde ejaculation (where the semen does exit the body at the time of ejaculation but instead transfers to the bladder), premature ejaculation or anejaculation (the lack of ejaculation) can also be reasons for male infertility (39).

In conclusion, the causes of male infertility are multifarious. Along with the assistance of emerging technology, the identification of genes for diagnostic purposes would provide better guidance to clinicians. The evaluation and management of male infertility during infertility treatment are of the utmost importance for couples.

\section{Peer-review: Externally peer-reviewed.}

Author Contributions: Conception/Design of study - M.S.; Data Acquisition - M.S.; Data Analysis/Interpretation - M.S.; Critical Revision of Manuscript - M.S.; Technical or Material Support - M.S.

Conflict of Interest: The author has no conflict of interest to declare.

Financial Disclosure: The author declared that this study has received no financial support.

\section{Hakem Değerlendirmesi: Dış bağımsız.}

Yazar Katkıları: Çalışma Konsepti/Tasarımı - M.S.; Veri Toplama - M.S.; Veri Analizi/Yorumlama - M.S.; İçeriğin Eleştirel İncelemesi - M.S.; Malzeme ve teknik destek - M.S.

Çıkar Çatışması: Yazar çıkar çatışması bildirmemiştir.

Finansal Destek: Yazar bu çalışmada finansal destek almadığını beyan etmiş̧ir.

\section{REFERENCES}

1. WHO. World Health Organisation (WHO) laboratory manual for the examination and processing of human semen Fifth edition. 2010.

2. Vander Borght $M$, Wyns $C$. Fertility and infertility: Definition and epidemiology. Clin Biochem 2018; 62: 2-10. [CrossRef]

3. Krausz C. Male infertility: pathogenesis and clinical diagnosis. Best Pract Res Clin Endocrinol Metab 2011; 25(2): 271-85. [CrossRef]

4. Esteves SC, Agarwal A. Novel concepts in male infertility. Int Braz J Urol 2011; 37(1): 5-15. [CrossRef]

5. Jenardhanan P, Panneerselvam M, Mathur PP. Effect of environmental contaminants on spermatogenesis. Semin Cell Dev Biol 2016; 59: 126-40. [CrossRef]

6. Stuppia L, Franzago M, Ballerini P, Gatta V, Antonucci I. Epigenetics and male reproduction: the consequences of paternal lifestyle on fertility, embryo development, and children lifetime health. Clin Epigenetics 2015; 7: 120. [CrossRef]
7. Horta F, Vollenhoven B, Healey M, Busija L, Catt S, Temple-Smith $P$. Male ageing is negatively associated with the chance of live birth in IVF/ICSI cycles for idiopathic infertility. Hum Reprod 2019; 34(12): 2523-32. [CrossRef]

8. Tuttelmann F, Ruckert C, Ropke A. Disorders of spermatogenesis: Perspectives for novel genetic diagnostics after 20 years of unchanged routine. Med Genet 2018; 30(1): 12-20. [CrossRef]

9. Cole LA. Chapter 18 - Human Male Spermatogenesis. In: Cole LA, editor. Biology of Life. Academic Press; 2016. p. 135-41. [CrossRef]

10. Ernst C, Eling N, Martinez-Jimenez CP, Marioni JC, Odom DT. Staged developmental mapping and $\mathrm{X}$ chromosome transcriptional dynamics during mouse spermatogenesis. Nat Commun 2019; 10(1): 1251. [CrossRef]

11. Fietz D, Bergmann M. Functional Anatomy and Histology of the Testis. In: Simoni M, Huhtaniemi I, editors. Endocrinology of the Testis and Male Reproduction. Cham: Springer International Publishing; 2017. p. 1-29. [CrossRef]

12. Szmelskyj I, Aquilina L, Szmelskyj AO. Chapter 2 - Anatomy and physiology of the reproductive system: Prerequirements for conception. In: Szmelskyj I, Aquilina L, Szmelskyj AO, editors. Acupuncture for IVF and Assisted Reproduction. Churchill Livingstone; 2015. p. 23-58. [CrossRef]

13. Guerri G, Maniscalchi T, Barati S, Busetto GM, Del Giudice F, De Berardinis $E$, et al. Non-syndromic monogenic male infertility. Acta Biomed 2019; 90(10-S): 62-7. [CrossRef]

14. Milani DAQ, Tadi P. Genetics, Chromosome Abnormalities. StatPearls [Internet]. StatPearls Publishing; 2020.

15. Plaseska-Karanfilska D, Noveski P, Plaseski T, Maleva I, Madjunkova S, Moneva Z. Genetic causes of male infertility. Balkan J Med Genet 2012; 15(Suppl): 31-4. [CrossRef]

16. Dong Y, Du RC, Jiang YT, Wu J, Li LL, Liu RZ. Impact of chromosomal translocations on male infertility, semen quality, testicular volume and reproductive hormone levels. J Int Med Res 2012; 40(6): 2274-83. [CrossRef]

17. Kaiser-Rogers K, Rao KW. Structural Chromosome Rearrangements. In: Gersen SL, Keagle MB, editors. The Principles of Clinical Cytogenetics. New York, NY: Springer New York; 2013. p. 139-74. [CrossRef]

18. Harton GL, Tempest HG. Chromosomal disorders and male infertility. Asian J Androl 2012; 14(1): 32-9. [CrossRef]

19. Krausz $C$, Hoefsloot $L$, Simoni M, Tuttelmann F, European Academy of A, European Molecular Genetics Quality N. EAA/EMQN best practice guidelines for molecular diagnosis of Y-chromosomal microdeletions: state-of-the-art 2013. Andrology 2014; 2(1): 5-19. [CrossRef]

20. Redon R, Ishikawa S, Fitch KR, Feuk L, Perry GH, Andrews TD, et al. Global variation in copy number in the human genome. Nature 2006; 444(7118): 444-54. [CrossRef]

21. Thapar A, Cooper M. Copy number variation: what is it and what has it told us about child psychiatric disorders? J Am Acad Child Adolesc Psychiatry 2013; 52(8): 772-4. [CrossRef]

22. Miyamoto T, Minase G, Shin T, Ueda H, Okada H, Sengoku K. Human male infertility and its genetic causes. Reprod Med Biol 2017; 16(2): 81-8. [CrossRef]

23. Okutman O, Rhouma MB, Benkhalifa M, Muller J, Viville S. Genetic evaluation of patients with non-syndromic male infertility. J Assist Reprod Genet 2018; 35(11): 1939-51. [CrossRef]

24. Xavier MJ, Salas-Huetos A, Oud MS, Aston KI, Veltman JA. Disease gene discovery in male infertility: past, present and future. Hum Genet 2020. https://doi.org/10.1007/s00439-020-02202-x [CrossRef]

25. Oud MS, Volozonoka L, Smits RM, Vissers L, Ramos L, Veltman JA. A systematic review and standardized clinical validity assessment of male infertility genes. Hum Reprod 2019; 34(5): 932-41. [CrossRef] 
26. Dieterich K, Soto Rifo R, Faure AK, Hennebicq S, Ben Amar B, Zahi $M$, et al. Homozygous mutation of AURKC yields large-headed polyploid spermatozoa and causes male infertility. Nat Genet 2007; 39(5): 661-5. [CrossRef]

27. Elinati E, Kuentz P, Redin C, Jaber S, Vanden Meerschaut F, Makarian J, et al. Globozoospermia is mainly due to DPY19L2 deletion via non-allelic homologous recombination involving two recombination hotspots. Hum Mol Genet 2012; 21(16): 3695-702. [CrossRef]

28. Dieterich K, Zouari R, Harbuz R, Vialard F, Martinez D, Bellayou H, et al. The Aurora Kinase C c.144delC mutation causes meiosis I arrest in men and is frequent in the North African population. Hum Mol Genet 2009; 18(7): 1301-9. [CrossRef]

29. Kuentz P, Vanden Meerschaut F, Elinati E, Nasr-Esfahani MH, Gurgan $\mathrm{T}$, lqbal $\mathrm{N}$, et al. Assisted oocyte activation overcomes fertilization failure in globozoospermic patients regardless of the DPY19L2 status. Hum Reprod 2013; 28(4): 1054-61. [CrossRef]

30. Yatsenko AN, Georgiadis AP, Ropke A, Berman AJ, Jaffe T, Olszewska $\mathrm{M}$, et al. X-linked TEX11 mutations, meiotic arrest, and azoospermia in infertile men. N Engl J Med 2015; 372(22): 2097-107. [CrossRef]

31. Okutman O, Muller J, Baert $\mathrm{Y}$, Serdarogullari M, Gultomruk M, Piton $\mathrm{A}$, et al. Exome sequencing reveals a nonsense mutation in TEX15 causing spermatogenic failure in a Turkish family. Hum Mol Genet 2015; 24(19): 5581-8. [CrossRef]

32. Wyrwoll MJ, Temel SG, Nagirnaja L, Oud MS, Lopes AM, van der Heijden GW, et al. Bi-allelic Mutations in M1AP Are a Frequent Cause of Meiotic Arrest and Severely Impaired Spermatogenesis Leading to Male Infertility. Am J Hum Genet 2020; 107(2): 342-51. [CrossRef]
33. Franca MM, Funari MFA, Nishi MY, Narcizo AM, Domenice S, Costa EMF, et al. Identification of the first homozygous 1-bp deletion in GDF9 gene leading to primary ovarian insufficiency by using targeted massively parallel sequencing. Clin Genet 2018; 93(2): 40811. [CrossRef]

34. Lorenzi D, Fernandez C, Bilinski M, Fabbro M, Galain M, Menazzi S, et al. First custom next-generation sequencing infertility panel in Latin America: design and first results. JBRA Assist Reprod 2020; 24(2): 104-14. [CrossRef]

35. Riera-Escamilla A, Enguita-Marruedo A, Moreno-Mendoza D, Chianese C, Sleddens-Linkels E, Contini E, et al. Sequencing of a 'mouse azoospermia' gene panel in azoospermic men: identification of RNF212 and STAG3 mutations as novel genetic causes of meiotic arrest. Hum Reprod 2019; 34(6): 978-88. [CrossRef]

36. Rocca MS, Msaki A, Ghezzi M, Cosci I, Pilichou K, Celeghin R, et al. Development of a novel next-generation sequencing panel for diagnosis of quantitative spermatogenic impairment. J Assist Reprod Genet 2020; 37(4): 753-62. [CrossRef]

37. Choi WS, Kim SW. Current issues in varicocele management: a review. World J Mens Health 2013; 31(1): 12-20. [CrossRef]

38. Garcia-Velasco JA, Banker M, Shah R. Infertility Management Series:Practical Management of Male Infertility. New Delhi, India: Jaypee Brothers Medical Publishers; 2015. [CrossRef]

39. Leaver RB. Male infertility: an overview of causes and treatment options. Br J Nurs 2016; 25(18): S35-S40. [CrossRef] 